\title{
New contract with DOE laboratories guarantees academic freedoms
}

\begin{abstract}
Washington. Researchers at some of the largest US national laboratories are about to get their first guarantee of something their academic colleagues take for granted: scientific and intellectual freedom. As part of a proposed new management contract with the University of California (UC), the Los Alamos, Lawrence Livermore and Lawrence Berkeley national laboratories will for the first time explicitly assure their $17,600 \mathrm{com}$ bined employees of the same rights as UC researchers.
\end{abstract}

These rights, although always professed, have never been in the contract with the US Department of Energy (DOE) to manage the three laboratories, two of which began as nuclear weapons laboratories and still maintain large classified research programmes. This omission has not been academic: in the past decade, dozens of scientists have been threatened and even muzzled for criticizing everything from the Star Wars missile defence system to Desert Storm and the US fusion programmes. Others have been forbidden to attend conferences attended by researchers from the Soviet Union and other nations seen as adversaries.

One who has suffered greatly from the blurring of scientific freedom is Hugh Dewitt, a theoretical physicist at Lawrence Livermore. After criticizing the laboratory's work on a X-ray laser weapon for the Star Wars project, Dewitt suffered the ignominy of monthly performance assessments and poor reviews and eventually left the laboratory for a year. By battling back on a platform of academic freedom, Dewitt was able to clear his name. But without the explicit guarantee of such freedom, Dewitt fought for years to have his right to free speech recognized.

He and other laboratory researchers say that the new language - assuring laboratory scientists of the "equivalent rights and obligations of university faculty" in publication, participation in open debate and attendance at scientific and professional meetings - should put an end to those sort of struggles. "Next time I get in trouble, I'm certainly going to wave that paragraph around", says Dewitt.

The proposed five-year contracts, released in final draft form last week, are the result of nearly a year and half of negotiations between DOE and UC. They must still be signed by DOE as well as by the UC board of regents, which is expected to approve them at a meeting this week.

But even getting this far has been an ordeal for the two parties. In 1989, UC faculty voted not to renew the contract because of concern over the university's affiliation with such a visible aspect of the US weapons complex. Although the regents subsequently voted to renew the contracts, DOE began having reservations of its own.

Beyond a lingering suspicion that the UC faculty would continue to prove an obstacle, DOE officials were concerned about UC's refusal to accept liability for environmental problems at the laboratories. Officials feared that could place DOE in the position of having to take the blame for and swallow the cost of - management problems that resulted in pollution.

Negotiations on the liability issue forced the UC regents to extend the current contract by two months in September. Yet when the dust settled, little had changed. UC will continue to be protected against liability or loss arising from its management of the laboratories. In return, UC accepted liability for any unallowable indirect costs, criminal fines and penalties or wilful misconduct by laboratory officials. DOE will put $\$ 14$ million annually into a contingency fund to pay for any such penalties. If UC can avoid such expenses, it can use the money as it sees fit, including supporting research involving $\mathrm{UC}$ and laboratory scientists.

Although the contract remains based on the idea of nonprofit management, UC's fee will more than double. In addition to its $\$ 14$ million contingency fee, $U C$ will receive $\$ 5$ million a year for the ground on which the Lawrence Berkeley Laboratory stands (although it has always been UC property, the university has never before charged rent) and another $\$ 5$ million for a new supervisory office. That office, with at least 30 employees, will watch for the kind of abuses that have led to faculty protests in the past.

Overall, the university's annual management fee will increase from $\$ 13$ million this year to $\$ 30$ million. Although the state will end up with some of that money, much of it is expected to support new collaborative research between UC and laboratory scientists and more frequent transfers of laboratory technology to the outside world.

Christopher Anderson

\section{Safeguards added for appeals in misconduct cases}

Washington. Responding to complaints that federal misconduct investigations do not allow scientists enough opportunity to defend themselves, the US Public Health Service has agreed to offer a full courtlike hearing to scientists found guilty of misconduct. But the new procedures, which could cost scientists thousands of dollars, may still not satisfy those who say that the system now deprives scientists of their right to a fair trial.

The Office of Research Integrity (ORI) is hoping the move will bring to misconduct investigations such basic rights as the ability to be represented by a lawyer, to crossexamine witnesses and to see evidence. This is intended to ameliorate concerns about its announced plans last month to limit further a scientist's rights under the Privacy Act to see his or her own records by obtaining an exemption to that act for misconduct inves- tigations (see Nature 359, 765; 1992). Although ORI says it will still seek such an exemption, it hopes that the new procedures will placate its critics.

Under the new regulations, any scientist found guilty of scientific misconduct after an investigation by ORI or the scientist's institution will automatically be offered an administrative hearing to review the case before either an administrative law judge or a panel of officials and scientists. Researchers will be able to question any ORI witnesses and evidence and to present their own evidence and witnesses in an effort to have the charges dropped. In a notice published in the Federal Register of 6 November, ORI said the new procedures would take effect immediately.

In the past, scientists facing debarment from future federal grants could request such a hearing, but they constitute only a quarter of those found guilty of misconduct. The others face lesser penalties, such as loss of single grant, prohibition from sitting on federal review committees and official reprimands. Now all will be entitled to an appeal hearing.

However, it is not known how many will request such an appeal. Only three of 13 scientists facing debarment have done so, according to Lyle Bivens, the ORI director, and only about half of those accused of misconduct maintain their innocence throughout the investigation and, presumably, would be inclined to request a hearing after its conclusion.

Even for those, cost may be a factor. The hearing can take weeks, and legal fees can exceed $\$ 50,000$. Given that no scientists have yet won such a hearing, it may take a brave researcher indeed to risk so much for a day in court. 